\title{
Efektivitas Proses Ozonisasi Studi Kasus : IPA dan Miniplant Dago Pakar
}

\author{
CHINDY CINTHYA, MOH.RANGGA SURURI, SITI AINUN \\ Jurusan Teknik Lingkungan, Fakultas Teknik Sipil dan Perencanaan, Institut \\ Teknologi Nasional, Bandung \\ Email: chindycinthya@gmail.com
}

\begin{abstract}
ABSTRAK
IPA dan Miniplant Dago Pakar merupakan salah satu Instalasi pengolahan air minum dengan sumber air baku berasal dari Sungai Cikapundung Hulu. Keberadaan kolam retensi yang berperan sebagai pre-treatment pada air baku Miniplant diperkirakan akan mempengaruhi karakteristik bahan organik pada air baku. Proses ozonisasi digunakan sebagai alternatif pengolahan bahan organik dengan menggunakan ozon yang berperan sebagai oksidator kuat. Tujuan dari penelitian ini adalah mengetahui efisiensi penyisihan BOD dan kekeruhan pada air baku dengan proses ozonisasi. Parameter yang diukur meliputi pH, temperatur, kekeruhan, BOD dan KSO dengan metode pengukuran mengacu kepada SNI dan SMWW. Penelitian dilakukan skala laboratorium menggunakan reaktor sistem batch selama 60 menit pada reaktor ozon kontaktor yang bervolume 1,5 L. Pengolahan dengan proses ozonisasi dapat mengoksidasi bahan organik menjadi senyawa yang lebih sederhana. Sampel air yang digunakan berasal dari air baku yang akan diolah di IPA dan Miniplant Dago Pakar. Efisiensi penyisihan kekeruhan pada IPA dan Miniplant secara berturut-turut adalah $77 \%$ dan 39\%. Nilai BOD pada IPA lebih tinggi dibandingkan dengan Miniplant yang diduga disebabkan oleh keberadaan kolam retensi. Konsentrasi BOD pada IPA setelah dilakukan ozonisasi mengalami peningkatan sebanyak 9\% sedangkan pada Miniplant peningkatan nilai BOD adalah $20 \%$.
\end{abstract}

Kata kunci: Air Baku, IPA dan Miniplant Dago Pakar, Ozonisasi, BOD, Kekeruhan

\author{
ABSTRACT


Water Treatment Plant (WTP) and Miniplant Dago Pakar is one of the Installation of drinking water treatment with raw water source from Cikapundung Hulu River. The existence of a retention pond that acts as a pre-treatment in Miniplant raw water is expected to affect the characteristics of organic matter in raw water. The ozonation process is used as an alternative to the processing of organic materials by using ozone which acts as a strong oxidzing agent. The purpose of this research is to know the efficiency of BOD removal and turbidity in raw water by ozonzation process. Parameters measured include $\mathrm{pH}$, temperature, turbidity, BOD and KSO with measurement method referring to SNI and SMWW. The study was conducted on a laboratory scale using a batch reactor system for 60 minutes on a $1.5 \mathrm{~L}$ volume of contactor ozone. Processing by ozonation process can oxidze organic materials into simpler compounds. Water samples used are from raw water to be processed in WTP and Miniplant Dago Pakar. The effectiveness removal of turbidity in WTP and Miniplant was $77 \%$ and $39 \%$, respectively. BOD values in IPA were higher than those in Miniplant that were thought to be due to the presence of retention pools. BOD concentration on WTP after ozonziation has increased by $9 \%$ while in Miniplant BOD value increase is $20 \%$.

Keywords: Raw Water, WTP and Miniplant Dago Pakar,Ozonation, BOD, Turbidity 


\section{PENDAHULUAN}

IPA dan Miniplant Dago Pakar merupakan salah satu Instalasi pengolahan air minum yang digunakan untuk memenuhi kebutuhan air minum wilayah Bandung Utara. Kedua Instalasi tersebut menerima pasokan air baku yang bersumber dari Sungai Cikapundung Hulu dengan debit pengolahan secara berturut-turut adalah 600 L/detik dan 40 L/detik. Pengolahan air baku pada IPA dan Miniplant memiliki perbedaan perlakuan, dimana air baku yang diolah oleh Miniplant akan dialirkan terlebih dahulu ke kolam retensi PLTA Dago Bengkok yang juga berperan sebagai kolam prasedimentasi untuk menyisihkan pratikel diskrit dan tersuspensi. Adanya perbedaan perlakuan tersebut akan mempengaruhi karakteristik dari air baku, sehingga pada penelitian ini akan ditunjukkan pengaruh dari proses prasedimentasi terhadap karakteristik air baku terutama terhadap kandungan bahan organik.

Air baku yang bersumber dari Sungai Cikapundung Hulu akan dipengaruhi oleh aktivitas yang terdapat pada bantaran sungai. Menurut hasil penelitian dari Astuti (2005), bahwa penduduk di wilayah Sungai Hulu Cikapundung sekitar 30\% memenuhi kebutuhan hidup dari peternakan terutama sapi perah, dimana setiap hari para peternak membuang kotoran sapi ke saluran-saluran yang bermuara ke sungai Sungai Cikapundung. Adanya kegiatan tersebut akan mempengaruhi kualitas air baku yang akan diolah pada IPA dan Miniplant terutama kandungan organik pada air baku yang akan menimbulkan berbagai dampak terhadap kinerja unit pengolahan.

Bahan organik dalam air pada umumnya berpengaruh terhadap proses pengolahan air seperti koagulasi, oksidasi, adsopsi, dan filtrasi (Sillanpaa, 2015). Selain itu, keberadaan bahan organik pada air baku dapat menghasilkan produk samping desinfektan, dimana proses desinfeksi di Indonesia masih menggunakan klor yang dapat membentuk produk samping berupa halogenated organic by products (Chowdhury \& Champagne, 2009).

Oleh karena itu, diperlukan strategi yang dapat diterapkan untuk mengurangi kehadiran bahan organik pada air baku. Ozonisasi merupakan salah satu proses pengolahan yang dapat digunakan untuk mengurangi bahan organik pada air baku. Ozon merupakan salah satu bahan dengan potensial reduksi oksidasi yang cukup tinggi, karena itu molekul ozon dapat bereaksi dengan berbagai senyawa dalam air (Beltrand, J Fernando, 1995). Keunikan dari proses ozonisasi adalah hasil dekomposisi ozon berupa $\mathrm{OH}$ radikal yang merupakan oksidator lebih kuat dan bersifat tidak selektif sehingga dapat mendegradasi bahan organik dalam air kompleks dalam air (Hoigné, Bader, Haag, \& Staehelin, 1985). 


\section{METODOLOGI}

Metodologi yang digunakan dalam penelitian dibagi menjadi beberapa tahapan sebagai berikut:

\subsection{Studi Literatur}

Tahap awal yang dilakukan adalah studi literatur, tahap ini diperlukan untuk mendukung dan memahami rumusan teoritis yang diperlukan pada penelitian ini. Studi literatur dilakukan terhadap buku-buku, hasil penelitian terkait terdahulu dan jurnal/ karya ilmiah yang berkaitan.

\subsection{Persiapan Sampling}

\subsubsection{Lokasi Pengambilan Sampel}

Air baku yang diolah pada IPA dan Miniplant Dago Pakar bersumber dari Sungai Cikapundung bagian hulu. Air baku yang akan diolah di Miniplant Dago Pakar akan dialirkan terlebih dahulu ke kolam retensi, sedangkan untuk IPA Dago Pakar air baku langsung dialirkan ke instalasi. Skema pengambilan air baku menuju instalasi dapat dilihat pada Gambar 1.
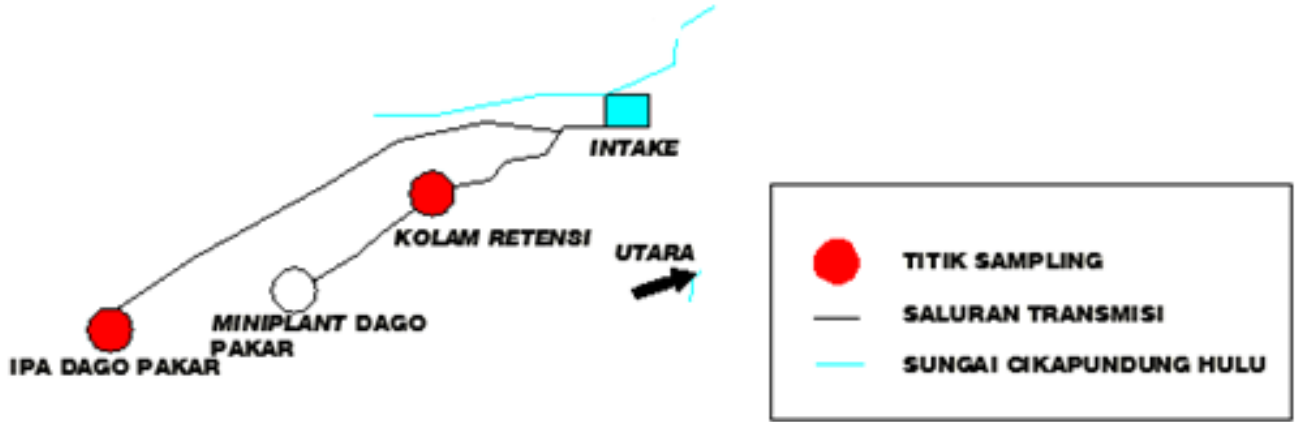

\section{Gambar 1. Skema Pengambilan Air Baku Pada Masing-Masing Instalasi}

Sampel air baku IPA Dago Pakar diambil dari inlet bak koagulasi, dimana air baku belum mengalami pencampuran dengan koagulan, sedangkan untuk sampel air baku Miniplant Dago Pakar diambil dari kolam retensi PLTA Dago Bengkok yang juga berperan sebagai kolam prasedimentasi.

\subsubsection{Waktu Pengambilan Sampel}

Pengukuran karakterisasi air sampel dilakukan sebanyak 12 kali dengan waktu sampling dilihat dari tingkat kekeruhan terendah harian yaitu pada pukul 09.00 WIB. Pengambilan sampel dilakukan secara composited, hal tersebut dikarenakan terdapat banyak faktor yang mempengaruhi masuknya pencemar bahan organik yang tidak dapat diprediksi sehingga diperlukan pengambilan sampel secara berkala agar diperoleh data yang dimiliki semakin valid.

\subsection{Persiapan Penelitian}

\subsubsection{Persiapan Alat dan Bahan}


Persiapan penelitian dilakukan untuk mempermudah dalam melakukan penelitian. Persiapan alat berupa penyusunan rangkaian reaktor ozonisasi yaitu aerator untuk mensuplai udara ke ozon generator, flow meter untuk mengukur udara yang masuk kedalam ozon generator dengan debit 2 L/menit, ozon generator untuk mengubah oksigen menjadi ozon, serta ozon kontaktor yang berfungsi sebagai tempat kontak antara ozon dengan air sampel yang memiliki volume $1,5 \mathrm{~L}$. Berikut merupakan rangkaian reaktor yang digunakan pada saat melakukan penelitian pada Gambar 2.

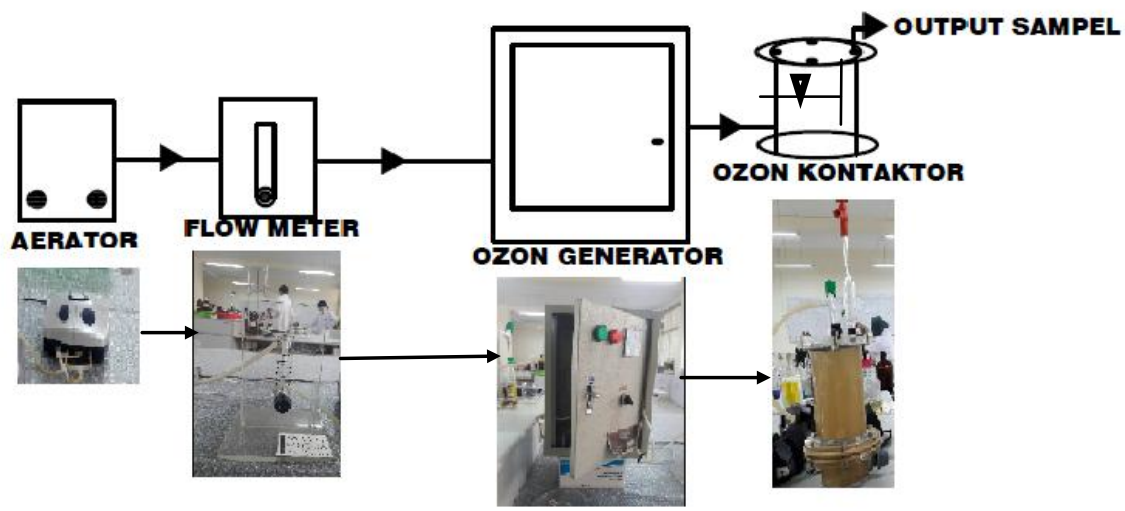

Gambar 2. Rangkaian Reaktor Ozon

Persiapan bahan meliputi persiapan bahan-bahan yang digunakan pada penelitian ini berdasarkan parameter yang diukur yaitu BOD menggunakan larutan air pengencer seperti larutan buffer fosfat, larutan $\mathrm{MgSO}_{4}$, larutan $\mathrm{CaCl}_{2}$ dan larutan $\mathrm{FeCl}_{3}$, untuk alkalinitas digunakan larutan $\mathrm{HCL} 0,1 \mathrm{~N}$ dan $\mathrm{NaOH} 0,1 \mathrm{~N}$, sedangkan untuk pengukuran konsentrasi sisa ozon digunakan larutan stok indigo.

\subsubsection{Pengukuran Karakteristik Air Baku}

Parameter fisik yang diukur mencakup $\mathrm{pH}$, temperatur dan Kekeruhan, sedangkan parameter kimia adalah alkalinitas, konsentrasi sisa ozon (KSO) dan pengukuran BOD yang menggambarkan bahan organik dalam air. Pengukuran $\mathrm{pH}$ dan temperatur dilakukan secara insitu, sedangkan pengukuran parameter lainnya dilakukan di Laboratorium Teknik Lingkungan Itenas. Metode yang digunakan untuk pemeriksaan karakteristik air baku dapat dilihat pada Tabel 1 berikut :

Tabel 1. Metode Pemeriksaan Karakteristik Air Baku

\begin{tabular}{|c|c|c|}
\hline Parameter & Metode & Sumber \\
\hline pH & Elektroda Potensiometri & SNI 06-6989.11-2004 \\
\hline Temperatur & Membrane Electrode & $\begin{array}{l}\text { Standard Method for the Examination of Water and } \\
\text { Wastewater 4500-O G Membrane Electrode method }\end{array}$ \\
\hline Alkalinitas & Titrasi Asam-Basa & SNI No. 06-2422-1991 \\
\hline $\begin{array}{l}\text { Konsentrasi } \\
\text { Sisa Ozon } \\
\text { (KSO) }\end{array}$ & Indigo Colorimetri & $\begin{array}{l}\text { Standard Methods for The Eximination Water and } \\
\text { Wastewater } 22 \text { th edtion } 4500-0_{3} \text {. Halaman 4-145 }\end{array}$ \\
\hline Kekeruhan & $\begin{array}{l}\text { Turbidimetri dengan alat } \\
\text { Turbidimeter Helliege }\end{array}$ & $\begin{array}{c}\text { Standard Method for the Examination of Water and } \\
\text { Wastewater 2130.B Nephelometric Method }\end{array}$ \\
\hline BOD & Titrasi Winkler & $\begin{array}{l}\text { SNI 6989.72:2009 Air dan Air Limbah-Bagian } 72: \\
\text { Cara Uji Kebutuhan Oksigen Biokimia (BOD) }\end{array}$ \\
\hline
\end{tabular}

Sumber : SNI dan SMWW 21 th Edition dan SNI

\subsubsection{Ozonisasi}


Pelaksanaan pengolahan bahan organik dan kekeruhan dilakukan dengan mengontakan ozon dan air dengan sistem batch, dengan prinsip kerjanya dengan memompakan udara bebas sebanyak 2 L/menit. Kandungan oksigen dalam udara akan menghasilkan ozon dalam fase gas, kemudian dikontakkan secara kontinu kedalam ozon kontaktor yang berisi sampel. Pemilihan waktu kontak ozon selama 60 menit berdasarkan hasil penelitian terdahulu akan menghasilkan produki ozon sebesar $50,56 \mathrm{mg} \mathrm{O}_{3} / \mathrm{L}$ (Wahyudin, 2013). Debit udara bebas yang digunakan pada penelitian ini adalah $2 \mathrm{~L} /$ menit yang akan menghasilkan produksi ozon 66,67 ppm/detik (Kharisma 2007 dalam Sururi 2008).

\section{HASIL PENELITIAN DAN PEMBAHASAN}

\subsection{Karakteristik Awal Sampel}

Karakteristik sampel air baku yang diukur yaitu $\mathrm{pH}$, temperatur, alkalinitas dan BOD. Sampling dilakukan pada pagi hari yaitu pukul 09.00 WIB. Berikut merupakan karakteristik sampel air baku yang digunakan untuk penelitian.

Tabel 2. Karakteristik Air Baku IPA dan Miniplant Dago Pakar

\begin{tabular}{cccc}
\hline \multirow{2}{*}{ Parameter } & \multirow{2}{*}{ Satuan } & \multicolumn{2}{c}{ Sa mpel A ir } \\
\cline { 3 - 4 } & & IPA & Miniplant \\
\hline pH & & $7,07 \pm 0,2$ & $7,11 \pm 0,3$ \\
\hline Temperatur & ${ }^{0} \mathrm{C}$ & $21,77 \pm 0,5$ & $21,83 \pm 0,47$ \\
\hline Kekeruhan & $\mathrm{NTU}$ & $23,42 \pm 12,7$ & $17,3 \pm 12,6$ \\
\hline \multicolumn{1}{c}{ BOD } & $\mathrm{mg} / \mathrm{l}$ & $9,16 \pm 5$ & $3,5 \pm 1,4$ \\
\hline Sumber : Hasil Penelitian, 2017 & &
\end{tabular}

Nilai pH pada IPA Dago Pakar dan Miniplant cenderung netral, sedangkan nilai temperatur pada kedua sampel relatif sama, hal tersebut disebabkan sumber air baku yang sama yaitu berasal dari Sungai Cikapundung Hulu. Nilai Kekeruhan dan BOD pada Miniplant lebih rendah dibandingkan dengan IPA, hal tersebut disebabkan keberadaan kolam retensi yang dapat menyisihkan nilai kekeruhan dan BOD pada air baku.

\subsection{Konsentrasi Sisa Ozon}

Pengukuran konsentrasi sisa ozon dilakukan setiap interval waktu kontak 10 menit. Nilai konsentrasi sisa ozon digunakan untuk mengetahui aktivitas ozon dalam sampel, dimana semakin tinggi nilai konsentrasi sisa ozon pada sampel menunjukkan ozon semakin aktif. Hasil pengukuran konsentrasi sisa ozon setiap interval waktu kontak selama proses ozonisasi dapat dilihat dari Gambar 3. 


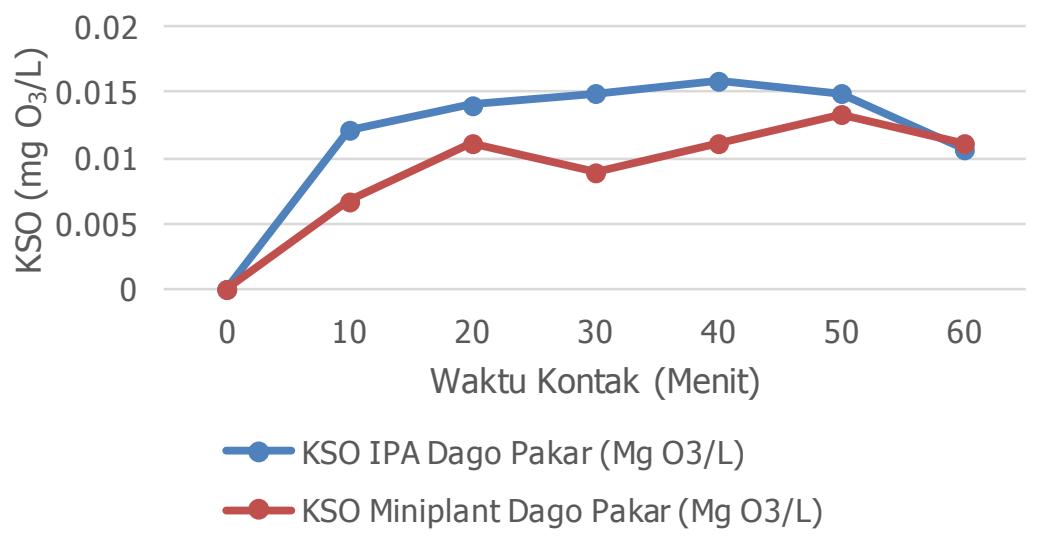

\section{Gambar 3.Konsentrasi Sisa Ozon Pada Sampel Air}

Gambar 3 menunjukkan konsentrasi sisa ozon pada IPA Dago Pakar dengan nilai tertinggi sebesar 0,0106 $\mathrm{mg} \mathrm{O}_{3} / \mathrm{L}$ pada menit ke-10, sedangkan nilai konsentrasi tertinggi pada Miniplant sebesar 0,0158 $\mathrm{mg} \mathrm{O}_{3} /$ Lpada menit ke-20. Kelarutan ozon Miniplant lebih rendah dibandingkan dengan IPA, nilai kelarutan ozon dalam air dipengaruhi oleh $\mathrm{pH}$, temperatur, alkalinitas dan natural organic matter (NOM) dalam air. Parameter pH dapat mempengaruhi stabilitas ozon dalam pembentukan $\mathrm{OH}$ radikal. $\mathrm{pH}$ yang tinggi menunjukkan kehadiran ion hidroksida yang tinggi pula. Kehadiran ion $\mathrm{OH}$ - dapat menginisiasi dekomposisi ozon sebagai langkah awal dalam pembentukan $\mathrm{OH}$ radikal. Pada waktu kontak ke-60 menunjukkan bahwa sisa ozon kedua sampel mengalami penurunan yang dapat disebabkan karena adanya peningkatan $\mathrm{pH}$ yang mempengaruhi dekomposisi menjadi $\mathrm{OH}$ radikal dapat dilihat pada reaksi berikut (Hoigné et al., 1985):

$$
\begin{gathered}
\mathrm{O}_{3}+\mathrm{OH}^{-} \rightarrow \mathrm{HO}_{2}^{-}+\mathrm{O}_{2}^{-} \\
\mathrm{O}_{3}+\mathrm{HO}_{2}^{-} \rightarrow \mathrm{OH}^{-}+\mathrm{O}_{2}^{-}+\mathrm{O}_{2}
\end{gathered}
$$

Sela in $\mathrm{pH}$, parameter yang mempengaruhi proses dekomposisi ozon membentuk $\mathrm{OH}$ radikal adalah alkalinitas. Alkalinitas pada air yang berperan sebagai inhibitor dalam pembentukan $\mathrm{OH}$ radikal, dimana ion karbonat dan bikarbonat akan bereaksi dengan $\mathrm{OH}$ radikal untuk membentuk karbonat radikal yang akan bereaksi dengan senyawa orgnaik dan anorganik yang hadir pada laju lamban (Hoigné et al., 1985). Bikarbonat maupun karbon merupakan penghambat reaksi berantai radikal dan bahkan dapat menyebabkan pembentukan kembali ozon yang dapat dilihat pada reaksi berikut :

$$
\begin{gathered}
\mathrm{CO}_{3}{ }^{2-}+\mathrm{HO}^{\bullet} \rightarrow \mathrm{CO}_{3}{ }^{--}+\mathrm{OH}^{-} \\
\mathrm{CO}_{3}{ }^{--}+\mathrm{O}_{3}{ }^{\bullet-} \rightarrow \mathrm{CO}_{3}{ }^{2-}+\mathrm{O}_{3}
\end{gathered}
$$

Nilai konsentrasi sisa ozon (KSO) pada IPA Dago Pakar lebih tinggi dibandingkan dengan Miniplant, hal tersebut dapat disebabkan nilai alkalinitas pada IPA lebih tinggi yaitu 36,8 $\mathrm{mg} / \mathrm{L}$ dibandingkan Miniplant dengan nilai $24,2 \mathrm{mg} / \mathrm{L}$, sehingga proses dekomposisi ozon pada IPA berkurang. tingginya nilai KSO pada IPA Dago Pakar menunjukkan reaksi yang terjadi pada sampel adalah reaksi langsung.

\subsection{Efisiensi Penyisihan Kekeruhan dan BOD}

Proses ozonisasi menyisihkan parameter kekeruhan pada air baku IPA dan Miniplant, sedangkan parameter BOD pada IPA dan Miniplant Dago Pakar mengalami peningkatan. 
Berikut merupakan tabel yang menunjukkan perubahan karakteristik sampel setelah dilakukan pengolahan dengan ozonisasi.

\section{Tabel 3. Karakteristik Air Baku setelah Ozonisasi}

\begin{tabular}{|c|c|c|c|c|c|c|}
\hline \multirow{3}{*}{ Para meter } & \multicolumn{5}{|c|}{ Sampel A ir } & \multirow{3}{*}{$\begin{array}{c}\text { П Penyisihan } \\
(\%)\end{array}$} \\
\hline & \multicolumn{2}{|c|}{ IPA Dago Pakar } & \multirow{2}{*}{$\begin{array}{c}\text { П Penyisihan } \\
(\%)\end{array}$} & \multicolumn{2}{|c|}{$\begin{array}{c}\text { Miniplant Dago } \\
\text { Pakar }\end{array}$} & \\
\hline & Awal & Akhir & & Awal & Akhir & \\
\hline $\begin{array}{l}\text { Ke keruhan } \\
\text { (NTU) }\end{array}$ & 17,5 & 4,05 & 77 & 7,1 & 4,3 & 39 \\
\hline BOD ( $\mathrm{mg} / \mathrm{l})$ & 3,1 & 3,4 & -9 & 5,2 & 6,5 & -20 \\
\hline
\end{tabular}

Sumber : Hasil Penelitian, 2017

Kekeruhan pada air baku disebabkan oleh partikel tersuspensi dan koloid dalam air. Tingginya nilai kekeruhan dapat menunjukkan keberadaan partikel tersuspensi yang dapat membantu pelekatan senyawa organik (Au, Alpert, \& Pernitsky, 2011). Selama proses ozonisasi, nilai kekeruhan pada kedua air baku mengalami penurunan yang disebabkan oleh adanya kontak dengan ozon maupun dengan hasil dekomposisi ozon yang berupa $\mathrm{OH}$ radikal. Berikut merupakan presentasi efisiensi penyisihan kekeruhan pada air baku IPA dan Miniplant yang dapat dilihat pada Gambar 4.

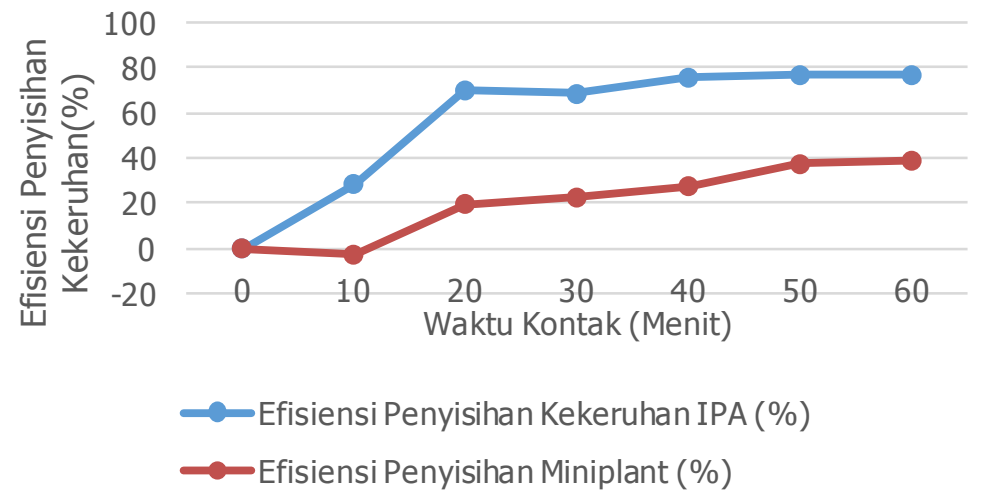

\section{Gambar 4. Efisiensi Penyisihan Kekeruhan Pada Air Baku IPA dan Miniplant Dago Pakar}

Gambar 4. menunjukkan bahwa dalam penyisihan kekeruhan pada air baku IPA dan Miniplant Dago Pakar mengalami peningkatan penyisihan nilai kekeruhan selama waktu kontak ozon. Nilai kekeruhan awal yang rendah pada Miniplant yang dapat disebabkan adanya penyisihan partikel diskrit dan tersuspensi sehingga pada air baku Miniplant lebih dominan mengandung padatan terlarut. Hal tesebut terlihat dari nilai kekeruhan awal yang rendah pada Miniplant Dago Pakar yaitu 7,1 NTU yang disebabkan oleh adanya penyisihan paratikel disrkrit secara gravitas sehingga yang tersisa adalah padatan terlarut dan koloid. Penyisihan kekeruhan pada air baku Miniplant lebih rendah dibandingkan IPA yang dapat disebabkan oleh adanya pemecahan asam humat yang terdapat dalam air baku yang mulanya bersifat terlarut menjadi tidak terlarut yang kemudian baru dilakukan penyisihan oleh ozon (Arya Rezagama, 2012).

Adanya penurunan nilai kekeruhan pada kedua air baku disebabkan oleh adanya destabilisasi koloid karena adanya kontak dengan ozon yang bermuatan positif sehingga koloid menjadi 
netral dan dapat mengendap. Selain itu, proses ozonisasi yang menyisihkan bahan organik akan menyebabkan kontak antara partikel-partikel lebih baik sehingga terbentuk flok pada permukaan (Rakness, 2005).

Proses ozonisasi akan menghasilkan Low Molecullar Weight (LMW) dimana produk tersebut dihasilkan dari oksidasi senyawa organik yang terpecah menjadi LMW yang merupakan senyawa yang mudah didegradasi (Sururi, 2008). Reaksi langsung pada proses ozonisasi berperan dalam perusakan mekanisme yang terjadi secara perlahan pada zat organik yang secara alamiah terdapat pada air menjadi asam karboksilat, aldehid, dan keton dan tidak langsung menjadi $\mathrm{CO}_{2}$. Pada awal proses ozonisasi, bahan organik yang akan lebih banyak diurai merupakan bahan organik yang lebih sederhana. Keberadaan bahan organik yang mudah terurai secara alami diwakili oleh pengukuran parameter BOD. Perubahan konsentrasi BOD selama proses ozonisasi dapat dilihat pada Gambar $\mathbf{5}$

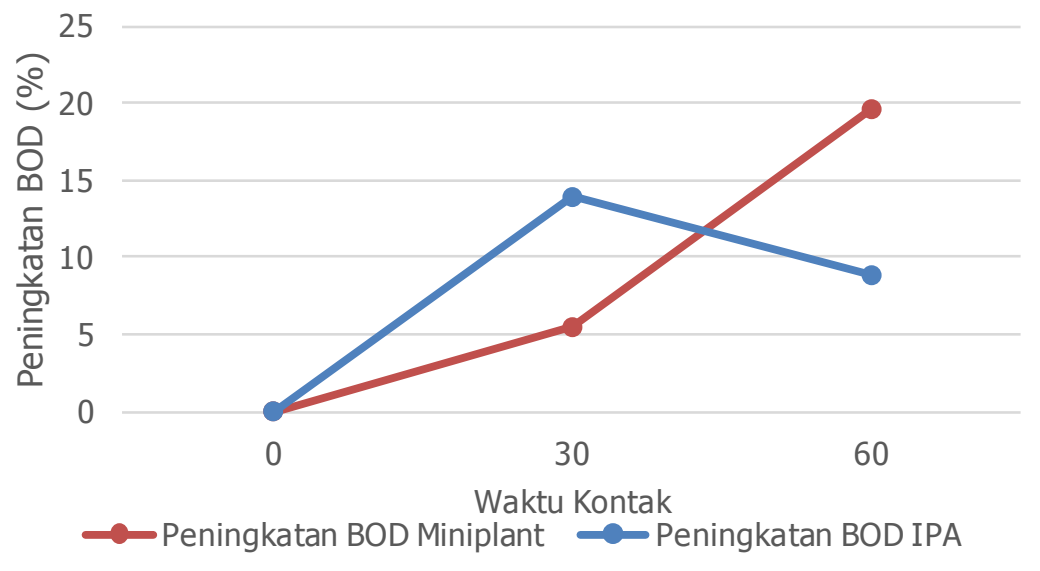

\section{Gambar 5. Peningkatan BOD IPA dan Miniplant Dago Pakar}

Gambar 5. menunjukkan bahwa terdapat peningkatan nilai BOD pada kedua air baku. Peningkatan BOD pada air baku disebabkan adanya pemecahan senyawa yang kompleks menjadi lebih sederhana sehingga dapat dengan mudah terdegradasi oleh mikroorganisme. Nilai BOD IPA Dago Pakar mengalami penurunan pada akhir waktu kontak yang disebabkan penurunan konsentrasi sisa ozon yang diperkirakan terjadi proses dekomposisi menjadi $\mathrm{OH}$ radikal yang merupakan oksidator lebih kuat dibandingkan ozon sehigga penyisihan bahan organik lebih efektif.

Air baku IPA Dago Pakar mengalami penurunan nilai BOD pada menit ke 60 yang diduga telah terjadi proses degradasi bahan organik menghasilkan $\mathrm{CO}_{2}$ dan $\mathrm{H}_{2} \mathrm{O}$ sebagai hasil dari proses degradasi yang paling diharapkan atau disebut juga sebagai mineralisasi sehingga bahan organik yang terbiodegradasi sudah terurai dan menyebabkan nilai BOD turun.

Proses ozonisasi berfungsi untuk mengoksidasi bahan organik dari senyawa kompleks menjadi senyawa yang lebih sederhana. Penurunan bahan organik yang kompleks dan diikuti dengan nilai BOD menunjukkan bahwa proses ozonisasi akan membentuk senyawa yang lebih bersifat biodegradable.

\section{KESIMPULAN}


Setelah dilakukan pengolahan, air baku pada IPA dan Miniplant Dago Pakar menggunakan proses ozonisasi konvensional dapat menyisihkan kekeruhan pada air baku IPA dan Miniplant secara berturut adalah $77 \%$ dan $39 \%$. Konsentrasi BOD pada kedua sampel mengalami peningkatan, pada air baku Miniplant terjadi peningkatan BOD sebesar $20 \%$ sedangkan pada air baku IPA Dago Pakar peningkatan nilai BOD adalah 9\%. Peningkatan BOD pada air baku dapat disebabkan karena oksidasi bahan organik pada air baku dari senyawa yang kompleks menjadi lebih sederhana sehingga dapat bersifat biodegrabilitas.

\section{DAFTAR RUJUKAN}

Arya Rezagama, S. N. (2012). KINETIKA TRANSFER OZON DAN TREN KEKERUHAN DALAM AIR LINDI DENGAN PENGOLAHAN OZONISASI.

Au, K., Alpert, S. M., \& Pernitsky, D. J. (2011). Particle and natural organic matter removal in drinking water. Operationa/ Control of Coagulation and Filtration Processes-Manual of Water Supply Practices, M37, 1-16.

Beltrand, Fernando J. 2004. Ozone Reaction Kinetics for Water and Wastewater. $22^{\text {th }}$ ed. America Public Helath Association: Washington, DC.

Chowdhury, S., \& Champagne, P. (2009). Risk from exposure to trihalomethanes during shower: probabilistic assessment and control. Science of the total environment, 4075), 1570-1578.

Hoigné, J., Bader, H., Haag, W., \& Staehelin, J. (1985). Rate constants of reactions of ozone with organic and inorganic compounds in water-III. Inorganic compounds and radicals. Water Research, 19(8), 993-1004.

Mohamad Rangga Sururi, K. P., Paramanita. (2008). PENYISIHAN BAHAN ORGANIK ALAMI PADA AIR PERMUKAAN DENGAN OZONISASI DAN OZONISASI - FILTRASI Purifikasi.

Rakness, K. L. (2005). Ozone in Drinking Water Treatment. American Water Works Association.

Sillanpaa, M. (2015). Natural Organic Matter in Water Characterization and Treatmen: IWA Publisher.

Wahyudin, R. T. T., Sri Wardanni. (2013). KOMBINASI OZONISASI, IRADIASI ULTRAVIOLET DAN ZEOLIT UNTUK DISINFEKSI AIR TANAH DAN PENENTUAN KONSENTRASI OZON DENGAN METODE SPEKTROFOTOMETRI UV-VISIBLE. kimia, 1, 126-132. 